\title{
Evaluation of Cluster Frontline Demonstrations on Production, Productivity, Profitability, Adoption and Horizontal Spread of Chickpea (Cicer arietinum Linn) in Dholpur District of Rajasthan, India
}

\author{
Laxman Prasad Balai*, Navab Singh, D. R. Sharma, Madho Singh and S. M. Meena
}

Krishi Vigyan Kendra, Dholpur, COA, Baseri (SKN Agriculture University, Jobner), India

*Corresponding author

\section{A B S T R A C T}

\begin{tabular}{|l|}
\hline K e y w o r d s \\
Cluster frontline \\
demonstrations, \\
Pulses, Yield, \\
technology and \\
Extension gap, \\
Adoption, \\
Horizontal spread, \\
Wilt \& pod borer \\
\hline Article Info \\
\hline $\begin{array}{l}\text { Accepted: } \\
\text { 24 October } 2020 \\
\text { Available Online: } \\
10 \text { November } 2020\end{array}$ \\
\hline
\end{tabular}

Cluster Frontline Demonstration (CFLDs) are one of the key extension tools for the transfer of technology at grass-root level that directly influence on horizontal as well as vertical spread of technology. Considering their limited critical input requirements, soil-enriching properties, suitability for growing in areas, where moisture (water) is limited, pulses occupy a unique place in our agriculture system. The present investigation was carried out to evaluate the performance of improved variety with the scientific package of practices (POP) on production, productivity and profitability adoption and horizontal spread of Chickpea. The Krishi Vigyan Kendra, Dholpur was conducted CFLDs on Chickpea varieties like GNG 1581 and GNG 1958 at farmer plots. The adopted villages were such as Bharli, Lokoopura, Chandrawali, Pattipura, Peepret, Kankret, Bhavanpura, Dadipura (Baseri Block), Sigorai, Gadarpur, Kasotikhera, Khorpura (Bari Block) Chaurakhera, Moosalpur (Saipau Block) and Khera (Dholpur Block) during Rabi season 2016-17 to 2019-20 under National Food Security Mission, Govt. of India. Four hundred CFLDs were conducted in 160 ha area with active participation of farmers and scientific staff of KVK. According to data analysis, the highest grain yield was obtained in demonstrated practices (DP) with an average of $2093 \mathrm{~kg} / \mathrm{ha}$ as compared to farmer practice (FP) with an average of $1769 \mathrm{~kg} / \mathrm{ha}$. Average seed index was recorded in DP $26.85 \mathrm{gm}$ as compared to $17.88 \mathrm{gm}$ in FP with percent average yield increase was recorded in DP 19.07 as compared to FP. The average net return (Rs 66,263.1/ha) was obtained in the DP and Rs $52,894.1$ /ha was in FP. The most important factor B:C ratio indicates that whether CFLD technology is profitable or not. The average benefit cost ratio was recorded higher in CFLDs (3.36) as compared to FP (3.08) during the period of research investigation. An average seedling, maturity and total wilting disease occurrence only $14.66,11.79 \& 26.45$, respectively showed wilting symptoms in DP as compared to $18.48,14.69 \& 33.18$, respectively in FP. Spraying of quinalphos $25 \mathrm{EC}$ at the pod initiation stage reduces pod borer attack, average pod borer infection was found in 11.01 DP as compared to 20.38 found in FP. An average extension gap, technology gap \& technology index between DP and FP was recorded $3.25 \mathrm{q} / \mathrm{ha}, 4.92$ qt/ha \& 18.90 percent, respectively. Thus, the results undoubtedly indicates that the use of improved varieties and POP with scientific intervention under CFLDs programme contribute, to increase the production, productivity and profitability of Chickpea. The farmers are shifting knowledge, changing attitude and developing skill in Dholpur district of Rajasthan. This formed greater awareness and motivated the other farmers to adopt DP of Chickpea. 


\section{Introduction}

Pulses are a great source of vitamins, proteins, minerals, are also popularly known as "rich man's vegetable" and "Poor man's meat". It contributes significantly to the nutritional security of the country (Singha et al., 2020). The frequency of consumption of pulses in the country is much higher than any other source of protein. Which indicates the importance of pulses in daily food habits (Raj et al., 2013). Besides, pulses possess several other qualities such as they improve soil fertility and physical structure of the soil, crop rotations, dry farming, fit in mixed/intercropping system and provide green pods for vegetables and nutritious fodder for cattle (Singh et al., 2015). India is producing 25.23 million tons of pulses from an area of 29.99 million ha, which holds largest share $(26 \%)$ of world's production and consumer $(30 \%)$ of total pulses of the world. It has been expected that India's population would get to 1.68 billion in 2030 from the present level of 1.31 billion (IIPR, 2030). The production share of important pulse crops is Chickpea (45.53\%), Pigeonpea (17.06 \%), Urdbean (13.40\%), Mungbean $(7.76 \%)$, Field pea $(5 \%)$ and Lentil (5\%). Major areas under pulses are in the states likewise Madhya Pradesh (33\%), Maharashtra (13\%), Rajasthan (12\%), Uttar Pradesh (9 \%), Karnataka (8\%), Andhra Pradesh (5\%), Gujarat (4\%), Jharkhand (3 $\%)$, Tamilnadu (2\%) and Telangana (2\%), which together accounts for about 91 percent of the total production (DES, 2018). The average productivity of pulses in Rabi season in the Rajasthan state is about $1159 \mathrm{~kg} / \mathrm{ha}$ in 2018-19 (Pocket Book of Agricultural Statistics, 2020).

In India, pulses have always received due awareness both in terms of the requirement by consumers and adequate programmatic maintain from the government at the production frontline. Addressing this concern of implication, the Ministry of Agriculture and Farmers Welfare, Govt. of India had initiated a nation-wide Cluster Frontline Demonstration (CFLD) programme under National Food Security Mission-Pulses (NFSM-Pulses) since 2015-16 (Singha et al., 2020). The scheme is implemented in a mission mode through a farmer-centric approach. The scheme aims to target the selected village by making available the improved technologies promotion and extend likewise improved seeds, Integrated Nutrient Management (INM), promotion of micronutrients/gypsum/bio fertilizers, farm machinery, weed management, Integrated Pest Disease Management (IPDM), extension activities like On and Off-campus training, Kisan gosthi, field day and mass media campaign. The ICAR through its Krishi Vigyan Kendras (KVKs) across the country has been implementing it. This CFLD programme on different pulse crops is boosting the production and productivity with improved varieties and location-specific technologies. KVKs are grass root level organizations intended for the application of technology through assessment, refinement and demonstration of confirmed produce technologies under different micro-farming situations in a district (Das, 2007). The main objective of the frontline demonstration is to show the worth or value of the technology. The area, production and productivity of pulses in Rajasthan and Dholpur are also quite low as compared to other states, national acreage and production. Chickpea (Cicer arietinum Linn) is a major pulse crop being grown in India occupies 38 percent area (28.28 million hectares) and 48 percent of the total pulse production (23.22 million tonnes) (Anonymous, 2020). The area under Chickpea in Dholpur is 623 hectare, producing 713 tonnes with productivity of $1152 \mathrm{~kg} / \mathrm{ha}$ (Raj Krishi, 2019-20). Average productivity of Chickpea in Dholpur district was noticed lower side $(1152 \mathrm{~kg} / \mathrm{ha})$ than the average 
potential yield $(2500 \mathrm{~kg} / \mathrm{ha})$. The cause of low productivity of chickpea is due to use of old varieties, higher seed rate, un-irrigated cultivation, unaware of weeds and broadcasting sowing method and biotic/abiotic stresses in the district. Among the biotic stress, wilt disease incidence in germination and maturity time and gram pod borer is a major pest occurring for 75 per cent pod damage in the crop (Krishan et al., 2007). In view of this, intensive interventions such as CFLDs on Chickpea were conducted at farmer's field in participatory mode by KVK, Dholpur to introduce and disseminate improved varieties of Chickpea to increase the crop yield during Rabi seasons of year 2016-17 to 2019-20.

\section{Materials and Methods}

Dholpur district comes under Agro-climatic Zone III B (Flood Prone Eastern Plain) of Rajasthan state and agriculturally, it is important district. The KVK, Dholpur conducted CFLDs under NFSM-pulses scheme during Rabi seasons of year 2016-17 to 2019-20. Evaluation of the performance of new varieties and package of practices (POP) on production, productivity and profitability of Chickpea the demonstrations were conducted. Interested farmers were identified with the help of Participatory Rural Appraisal (PRA) technique. Finally, primarily selection of farmer and their fields for demonstration were based on the active participation of farmers and scientists of KVK. Assessment of gap in adoption of recommended technology by the farmers was taken before laying out the CFLDs through personal discussion with selected farmers. The geo-mapping of selected farmer's field for conducting the CFLDs was done (Table-1). The adopted villages were Bharli, Lokoopura, Chandrawali, Pattipura, Peepret, Kankret, Bhavanpura, Dadipura, Sigorai, Gadarpur, Kasotikhera, Khorpura, Chaurakhera,
Moosalpur and Khera during reporting year of Dholpur district. Four hundred CFLDs on Chickpea was laid out covering the total area of 160 ha with demonstration practices (DP) ranging from 0.40 ha (one acre). All critical inputs viz. improved varieties viz. GNG 1581 and GNG 1958 were demonstrated with full POP i.e. field preparation, seed rate, time of sowing, line sowing method, balance dose of fertilizer (20 kg Nitrogen $40 \mathrm{~kg} \mathrm{P}_{2} \mathrm{O}_{5} / \mathrm{ha}$ ), seed treatment (carbendazim $2.5 \mathrm{gm} / \mathrm{kg}$, imidacloropid $7 \mathrm{ml} / \mathrm{kg}$, Trichoderma harzanuim $7 \mathrm{gm}$ per $\mathrm{kg}$ and Rhizobium culture @ $5 \mathrm{gm} / \mathrm{kg}$ ) of seed, $20 \mathrm{~kg}$ per ha zinc sulphate, irrigation, weed management and plant protection measure were applied (Table 2) at farmers' fields. Crop was sown between October 3rd week to November first week with a spacing of $30 \mathrm{~cm} \times 10 \mathrm{~cm}$ and seed rate $75 \mathrm{~kg} / \mathrm{ha}$. The entire dose of $\mathrm{N}$ and $\mathrm{P}$ was applied as basal dose at the time of sowing. The farmer practice (FP) was considered as control plot (local check), which was maintained by the farmers according to their own traditional cultivation practices with old varieties. Training programmes were organized for selected farmers on improved technology of pulse production including high yielding variety, seed treatment, recommended chemicals (weedicides, fungicides \& pesticides), literature and regular visit, monitoring of pest and disease in crop advisory services management by the KVK scientist. Finally, field day and crop cutting experiment were conducted involving partner farmers, other farmers in the village, Scientists from University and ATARI, Jodhpur officials from local extension functionaries, Department of Agriculture to demonstrate the superiority of the technology demonstrated. Crop yield was recorded from the DP and FP plots for the crops at the time of harvesting during last week of March to the first week of April. The most feasible technique by which, this could be achieved is by demonstrating the recommended improved 
technology on the partner farmer's fields through CFLDs with the objectives to work out the input cost and monetary returns between DP and FP methods and to identify the yield gaps between FP and DP. The basic information was record from the farmer's field and analyzed to comparative performance of DP and FP. However, data about adoption and horizontal spread of technologies were collected from the participating farmers with help of interview schedule. The average prices of inputs and outputs commodities prevail during each reporting year of demonstrations were taken for calculating cost of cultivation, net return and benefit cost ratio. The yield data were collected from both the DP and FP by random crop cutting method and analyzed by using simple statistical tools. To study the yield attributes, twenty five plants were selected by randomly placing of quadrate at five places in DP plots as well as in FPs plots and five plants selected from each quadrate. Yield data from demonstration and FPs' were collected after harvesting the crop. For the recording of seed index (100 seeds) was taken and weighed. Economical assessment was done as per prevailing market prices or minimum support price. The technology gap, extension gap and technology index were calculated as suggested by Samui et al., (2003) and Dayanand et al., (2012) were calculated by using following formula as given below:

Percent increase yield $=\frac{\text { Demonstration yield }- \text { Farmers yield }}{\text { Farmers yield }} \times 100$

Extension gap = Demonstrated yieldFarmer's practice yield

Technology gap $=$ Potential yieldDemonstration yield

Additional return $=$ Demonstration practices return - Farmer's practice return
Technology index $=\frac{\text { Potential yield }- \text { Demonstration yield }}{\text { Potential yield }} \times 100$

Effective gain $(\mathrm{Rs} / \mathrm{ha})=$ Additional returns of DP (Rs/ha) - Additional cost of DP (Rs/ha)

Benefit cost ratio $(\mathrm{BCR})=\frac{\text { Gross return }(\mathrm{Rs} / \mathrm{ha})}{\text { Gross expenditure }(\mathrm{Rs} / \mathrm{ha})}$

\section{Disease incidence}

To assess the disease incidence, each DP \& FP fields were observed in CFLDs and average incidence of the disease in CFLDs was calculated. In each field, marked randomly, diseased and healthy plants were counted in one square meter area, in a field, four such spots were randomly selected and average incidence of field was calculated. The percent disease incidence (PDI) was calculated as per formula given below.

Percent Disease Incedence $=\frac{\text { No. of infected plant }}{\text { Total No. of plant observed }} \times 100$

\section{Percent pod damage}

The numbers of $H$. armigera larvae were counted on five randomly selected plants in each DP \& FP plot. Count damage pods and healthy pods on selected plant. Pod damage percentage was calculated using the following formula:

Percent Pod damage $=\frac{\text { No. of affected pod }}{\text { Total No. of pods }} \times 100$

\section{Adoption}

To measure the extent of adoption of Chickpea DP by the partner farmers, an adoption test was developed. Eleven major practices of Chickpea DP were included in the test. Each selected practice was further divided into several sub sections. The 
response under each sub-item was taken on a three point continuum viz., "always", "sometime" and "never" which were assigned 2, 1 and 0 score, respectively. The minimum and maximum scores which a respondent could obtain on this scale were 0 and 46, respectively.

\section{Results and Discussion}

The gap analysis between the DP and existing FP under Chickpea is presented in Table 2. Highest gap (98\%) was observed in case of use of bio-fertilizer followed by seed treatment, disease management, application of $\mathrm{N} \& \mathrm{P}$ and use of variety with $90,85,50$ and 35 per cent, respectively. Quality bio fertilizers are not in reach of farmers. Farmers are not aware about seed treatment and having no knowledge about disease management and applying N \& P fertilizers without soil testing. The reason behind higher gap is less extension workers are there in the district Dholpur. Farmers are dependent on advice of retail agri-input dealers those are less educated and having no knowledge about agriculture practices.

The year-wise details of demonstrations conducted by KVK, Dholpur in the adopted village are presented in Table 3. In each CFLD, suitable varieties of chickpea namely; GNG 1581 \& GNG 1958 were considered along with their recommended POP. While in FP, locally available old variety of selected Chickpea with traditional FP was followed by the farmers in their local farming situations. A total number of 400 demonstrations covering 160 ha were conducted by the KVKs at farmers' field during Rabi season 2016-17 to 2019-20 (Table 3 \& 4).

\section{Grain yield}

The yield of Chickpea obtains over the reported year under improved technology as well as FP is presented in Table 3. The CFLDs productivity of Chickpea ranged from 1950 to $2163 \mathrm{~kg} / \mathrm{ha}$ with average yield of $2093 \mathrm{~kg} / \mathrm{ha}$ under DP on farmers field as against a yield ranged from 1600 to 1861 $\mathrm{kg} / \mathrm{ha}$ with a mean of $1769 \mathrm{~kg} /$ ha recorded under FP. Seed index was recorded ranged from $16.4 \mathrm{gm}$ to $31.0 \mathrm{gm}$ in DP as compared to ranged $14.5 \mathrm{gm}$ to $20.0 \mathrm{gm}$ in FP. Average seed index recorded in DP was $26.85 \mathrm{gm}$ as compared to $17.88 \mathrm{gm}$ in FP. Percent yield increase of Chickpea ranged from 16.04 to 21.88 with average 19.07 under DP as compared to FP.

The higher productivity, seed yield index and percent yield increase were found in the DP as compared to FP during the reporting period, which might be due to continuous use of Integrated Pest Disease and Nutrient Management practices. The higher yield of Chickpea under DP was due to the use of latest high yielding varieties, integrated nutrients management, pest and disease management. The results have been also similar findings by Verma (2013), Rachhoya et al., (2018), Biradar et al., (2020) and Singha et al., (2020).

\section{Economical evaluation}

The input and output prices of commodities prevailed during each year of demonstration were taken for calculating cost of cultivation, net return, additional net return and benefit cost ratio (Table 4). The net return from DP was found Rs. 49,500 to Rs. 76,481.50. While the net return from FP range from Rs $38,000.00$ to Rs $64,832.5$ was recorded. It means that net return from DP was higher than the FP.

The additional cost of Rs. 1,800 to Rs 3,086 gave additional net return; it ranged from Rs. $11,500.00$ to Rs. $17,615.00$ per hectare. The increased benefit-cost ratio was also 
calculated; it ranged from 2.73 to 3.66 in DP as compared to 2.46 to 3.51 in FP was recorded. Thus, and it was clearly showed that the demonstration of Chickpea with full package was better than FP. Similar result has been reported by Rachhoya et al., (2018), Biradar et al., (2020) and Singha et al., (2020).

\section{Disease incidence}

Data recorded on plants infested with wilt (Fusarium wilt) caused by Fusarium oxysporum f.sp. ciceris revealed that, incidence of disease was lower in DP as compared to FP (Table-5). It was observed that on seedling stage, maturity stage and total wilting in wilt disease occurrence ranged from 13.88 to $15.66,10.43$ to $12.78 \& 25.07$ to 28.44 , respectively was observed in DP as compared to 17.66 to $19.23,13.25$ to 15.64 \& 31.90 to 34.82 , respectively in FP. An average seedling, maturity and total wilting disease occurrence were recorded at 14.66, 11.79 \&
26.45 respectively showed wilting symptoms in DP as compared to $18.48,14.69 \& 33.18$, respectively in FP. This could be responsible due to seed treatment. The findings are in line with the results reported by Gangwar et al., (2013), Rachhoya et al., (2018) and Nathawat et al., (2020).

\section{Insect infestation}

During the investigation, data as recorded (Table 5) on the infestation of pod borer (Helicoverpa armigera) caused premature dry and shading of pods. Spraying of quinalphos 25 EC @ $2.0 \mathrm{ml} /$ liter water at the time of pod initiation caused lesser pods infected ranged from 10.33 to 11.25 in DP as compared to FP ranged from 19.45 to 21.77 .

Average infected found in 11.01 DP as compared to 20.38 found in FP. Similar results quoted by Hossain et al., (2010) \& Patil et al., (2018a) and Rachhoya et al., (2018).

Table.1 The geo-mapping of selected farmers field for conducting the CFLDs was done

\begin{tabular}{|l|l|l|l|l|}
\hline $\begin{array}{l}\text { Sr. } \\
\text { No. }\end{array}$ & Village & Block & Longitude & Latitude \\
\hline $\mathbf{1}$ & Bharli & Baseri & 77.504 & 26.811 \\
\hline $\mathbf{2}$ & Lokoopura & Baseri & 77.300 & 26.507 \\
\hline $\mathbf{3}$ & Chandrawali & Baseri & 77.336 & 26.517 \\
\hline $\mathbf{4}$ & Peepret & Baseri & 77.453 & 26.594 \\
\hline $\mathbf{5}$ & Pattipura & Baseri & 77.617 & 26.829 \\
\hline $\mathbf{6}$ & Kankret & Baseri & 77.438 & 26.582 \\
\hline $\mathbf{7}$ & Bhavanpura & Baseri & 77.467 & 26.596 \\
\hline $\mathbf{8}$ & Dadipura & Baseri & 77.623 & 26.822 \\
\hline $\mathbf{9}$ & Sigorai & Bari & 77.592 & 26.702 \\
\hline $\mathbf{1 0}$ & Gadarpur & Bari & 77.451 & 26.652 \\
\hline $\mathbf{1 1}$ & Kasotikhera & Bari & 77.626 & 26.579 \\
\hline $\mathbf{1 2}$ & Khorpura & Bari & 77.461 & 26.685 \\
\hline $\mathbf{1 3}$ & Chaurakhera & Saipau & 77.801 & 26.793 \\
\hline $\mathbf{1 4}$ & Moosalpur & Saipau & 77.232 & 26.633 \\
\hline $\mathbf{1 5}$ & Khera & Dholpur & 77.892 & 26.755 \\
\hline
\end{tabular}


Table.2 Gap analysis among recommended practice \& farmers' practice Chickpea growers

\begin{tabular}{|c|c|c|c|c|}
\hline S. No & Technology & Recommended Practice & Farmers' practice & $\operatorname{Gap}(\%)$ \\
\hline 1. & Variety & RSG-888, GNG-1581 & C. 235 , GNG-1581 & 35 \\
\hline 2. & Seed Treatment & $\begin{array}{l}\text { Carbendazim }(2.0 \mathrm{~g} / \mathrm{kg} \text { seed }) \text { or } \\
\text { Trichoderma @ } 7 \mathrm{~g} / \mathrm{kg} \mathrm{seed} \text {, } \\
\text { Chloropyriphos @ } 8 \mathrm{ml} / \mathrm{kg} \text { seed }\end{array}$ & $10 \%$ application & 90 \\
\hline \multirow[t]{4}{*}{3.} & \multicolumn{4}{|c|}{ Fertilizers (kg/ha) Irrigated } \\
\hline & $\mathrm{N}$ & 20 & $\begin{array}{l}14.4 \mathrm{~kg} / \mathrm{ha}=50 \% \\
10.8 \mathrm{~kg} / \mathrm{ha}=40 \% \\
<7.2 \mathrm{~kg} / \mathrm{ha}=10 \%\end{array}$ & 50 \\
\hline & $\mathrm{P}$ & 40 & $\begin{array}{l}36.8 \mathrm{~kg} / \mathrm{ha}=50 \% \\
27.6 \mathrm{~kg} / \mathrm{ha}=40 \% \\
<18.4 \mathrm{~kg} / \mathrm{ha}=10 \%\end{array}$ & 50 \\
\hline & Bio-fertilizer & $\begin{array}{l}\text { Rhizobium }(150 \mathrm{ml}) \\
\text { PSB }(150 \mathrm{ml})\end{array}$ & $2 \%$ application & 98 \\
\hline 4. & $\begin{array}{l}\text { Disease Management } \\
\text { (wilt \& blight) }\end{array}$ & $\begin{array}{l}\text { Blight: Spray Copper Oxychloride } \\
0.3 \% \\
\text { Wilt: Soil treatment with } \\
\text { Trichoderma @ } 2.5 \mathrm{~kg} / \mathrm{ha}\end{array}$ & $15 \%$ application & 85 \\
\hline 5. & $\begin{array}{l}\text { Insect Management } \\
\text { (Pod borer) }\end{array}$ & Carbaryl $5 \%$ dust @20-25 kg /ha & $65 \%$ application & 35 \\
\hline
\end{tabular}

Table.3 Performance of technological intervention (CFLDs) on yield and yield attributes of Chickpea

\begin{tabular}{|c|c|c|c|c|c|c|c|c|c|c|c|}
\hline \multirow[t]{2}{*}{ Year } & \multirow[t]{2}{*}{ Variety } & \multirow{2}{*}{$\begin{array}{l}\text { Potentia } \\
\text { l yield } \\
\text { (Kg ha- } \\
\text { 1) }^{\text {Ko }}\end{array}$} & \multirow[t]{2}{*}{$\begin{array}{l}\text { Area } \\
\text { (ha) }\end{array}$} & \multirow[t]{2}{*}{ Demo } & \multicolumn{2}{|c|}{$\begin{array}{l}\text { Plant Population } \\
\left(\mathbf{N o} / \mathbf{m}^{2}\right)\end{array}$} & \multicolumn{2}{|c|}{$\begin{array}{l}\text { Seed yield } \\
\left.\text { (Kg ha- }^{1}\right)\end{array}$} & \multicolumn{2}{|c|}{$\begin{array}{l}\text { Seed index } \\
\text { (g/100 seeds) }\end{array}$} & \multirow{2}{*}{$\begin{array}{l}\text { Percent } \\
\text { increase } \\
\text { over } \\
\text { control } \\
\text { (FP) }\end{array}$} \\
\hline & & & & & DP & FP & DP & FP & DP & FP & \\
\hline 2016-17 & GNG 1581 & 2300 & 20 & 50 & 43 & 39 & 1950 & 1600 & 16.4 & 14.5 & 21.88 \\
\hline 2017-18 & GNG 1958 & 2680 & 50 & 125 & 42 & 38 & 2100 & 1793 & 30.0 & 18.0 & 19.66 \\
\hline 2018-19 & GNG 1958 & 2680 & 60 & 150 & 40 & 37 & 2163 & 1820 & 30.0 & 19.0 & 18.68 \\
\hline 2019-20 & GNG 1958 & 2680 & 30 & 75 & 41 & 37 & 2159 & 1861 & 31.0 & 20.0 & 16.04 \\
\hline \multicolumn{2}{|l|}{ Average } & 2585 & 160 & 400 & 41.5 & 37.75 & 2093 & 1769 & 26.85 & 17.88 & 19.07 \\
\hline
\end{tabular}

DP=Demonstration Practices, FP= Farmer Practices

Table.4 Economical comparison between demonstration practice and farmers' practice of chickpea

\begin{tabular}{|c|c|c|c|c|c|c|c|c|c|c|}
\hline \multirow[t]{2}{*}{ Year } & \multicolumn{2}{|c|}{$\begin{array}{l}\text { Gross cost } \\
\text { (Rs. ha- }^{1} \text { ) }\end{array}$} & \multicolumn{2}{|c|}{$\begin{array}{l}\text { Gross return } \\
\left(\text { Rs. ha- }^{1}\right)\end{array}$} & \multicolumn{2}{|c|}{$\begin{array}{l}\text { Net return } \\
\left(\text { Rs. ha- }{ }^{1}\right)\end{array}$} & \multirow[t]{2}{*}{$\begin{array}{l}\text { Additional } \\
\text { return }\end{array}$} & \multirow{2}{*}{$\begin{array}{l}\text { Effective } \\
\text { gain } \\
\text { (Rs/ha) }\end{array}$} & \multicolumn{2}{|c|}{ B: C Ratio } \\
\hline & DP & FP & DP & FP & DP & $\mathrm{FP}$ & & & RP & FP \\
\hline 2016-17 & 28600 & 26000 & 78000 & 64000 & 49500 & 38000 & 11500 & 8900 & 2.73 & 2.46 \\
\hline 2017-18 & 26700 & 24900 & 94215 & 74800 & 67515 & 49900 & 17615 & 1800 & 3.53 & 3.00 \\
\hline 2018-19 & 28326 & 25240 & 99792 & 84084 & 71556 & 58844 & 12712 & 9626 & 3.52 & 3.33 \\
\hline 2019-20 & 28786 & 25875 & 105267.5 & 90707.5 & 76481.5 & 64832.5 & 11649 & 8738 & 3.66 & 3.51 \\
\hline Average & 28103 & 25503.8 & 94318.6 & 78397.9 & 66263.1 & 52894.1 & 13369.1 & 7266 & 3.36 & 3.08 \\
\hline
\end{tabular}


Table.5 Impact of technological intervention on disease and pest infestation of chickpea

\begin{tabular}{|c|c|c|c|c|c|c|c|c|}
\hline \multirow[t]{3}{*}{ Year } & \multicolumn{6}{|c|}{ Percent disease incidence } & \multirow{2}{*}{\multicolumn{2}{|c|}{ Infected Pods }} \\
\hline & \multicolumn{2}{|c|}{ Seedling Stage } & \multicolumn{2}{|c|}{ Maturity stage } & \multicolumn{2}{|c|}{ Total wilting } & & \\
\hline & DP & FP & DP & FP & DP & FP & DP & FP \\
\hline 2016-17 & 14.65 & 18.65 & 10.43 & 13.25 & 25.08 & 31.90 & 11.85 & 21.77 \\
\hline 2017-18 & 13.88 & 17.66 & 11.19 & 14.29 & 25.07 & 31.95 & 10.77 & 19.45 \\
\hline 2018-19 & 14.45 & 18.39 & 12.77 & 15.64 & 27.22 & 34.03 & 11.29 & 20.55 \\
\hline 2019-20 & 15.66 & 19.23 & 12.78 & 15.59 & 28.44 & 34.82 & 10.13 & 19.74 \\
\hline Average & 14.66 & 18.48 & 11.79 & 14.69 & 26.45 & 33.18 & 11.01 & 20.38 \\
\hline
\end{tabular}

Table.6 Impact of CFLDs on extension, technology gap and yield index of chickpea

\begin{tabular}{|c|c|c|c|}
\hline Year & Extension gap (qt ha- ${ }^{1}$ ) & Technology gap (qt ha- ${ }^{1}$ ) & Technology Index (\%) \\
\hline 2016-17 & 3.5 & 3.5 & 15.22 \\
\hline 2017-18 & 3.07 & 5.8 & 21.64 \\
\hline 2018-19 & 3.43 & 5.17 & 19.29 \\
\hline 2019-20 & 2.98 & 5.21 & 19.44 \\
\hline Average & 3.25 & 4.92 & 18.90 \\
\hline
\end{tabular}

Table.7 Impact of CFLDs on horizontal spread of variety of chickpea in Dholpur district

\begin{tabular}{|l|l|l|l|l|l|}
\hline Variety & \multicolumn{2}{|l|}{ Area (ha) } & $\begin{array}{l}\text { Change in area } \\
\text { (ha) }\end{array}$ & $\begin{array}{l}\text { Impact } \\
\text { change) }\end{array}$ & (\% \\
\cline { 2 - 6 } & $\begin{array}{l}\text { Before } \\
\text { demonstration }\end{array}$ & $\begin{array}{l}\text { After } \\
\text { demonstration }\end{array}$ & & & \\
\hline GNG 1581 \& GNG 1958 & 125 & 550 & 425 & 29.41 \\
\hline
\end{tabular}

Table.8 Adoption of Chickpea production technology by the partner farmers

\begin{tabular}{|l|l|c|c|}
\hline SN & Package of practices & \multicolumn{2}{|c|}{ Partner farmers } \\
\hline 1. & HYVs & 100.00 & 1 \\
\hline 2. & Soil treatment and field preparation & 22.30 & 10 \\
\hline 3. & Seed treatment & 68.50 & 5 \\
\hline 4. & Time of sowing & 74.62 & 3 \\
\hline 5. & Seed rate and spacing & 86.00 & 2 \\
\hline 6. & Fertilizer application & 65.70 & 6 \\
\hline 7. & Irrigation management & 71.25 & 4 \\
\hline 8. & Weed management & 39.65 & 8 \\
\hline 9. & Plant protection measures & 18.75 & 11 \\
\hline 10. & Physiological aspects (nipping) & 25.50 & 9 \\
\hline 11. & Harvesting, threshing \& storage & 66.00 & 7 \\
\hline
\end{tabular}




\section{Extension gap}

The extension gap showed an increasing style. The extension gap range between 2.98 to 3.5 $\mathrm{q} / \mathrm{ha}$ (Table 6) during the period of study highlight the need to educate the farmers through various means for the adoption of improved agriculture production. The trends of technology gap reflected the farmers' cooperation in carrying out such demonstration with encouraging results in sequent year. The technology group observed may be attributed to the dissimilarity in soil fertility status and weather conditions.

The technology gap was recorded from 3.5 to 5.8 qt ha- ${ }^{1}$. The technology index showed the achievability of the evolved technology at the farmer's field. The lower value of technology index more is the feasibility of the technology demonstrated (Sagar and Chandra, 2004, Rachhoya et al., 2018, Biradar et al., 2020 and Singha et al., 2020). As such, reduction in technology index from 15.22 to 21.44 percent recorded during reported year exhibited the feasibility of the demonstrated technology in this district. These results confirm the findings of crop technology demonstration on Chickpea crops by Yadav et al., (2003), Lathwal (2010), Rachhoya et al., (2018), Biradar et al., (2020) and Singha et al., (2020). From the above findings, it can be windup that use of scientific method of Chickpea cultivation can decrease the technology gap to a considerable extent. This will lead to increase productivity of Chickpea in the district. Moreover extension agencies in the district need to provide proper technical support to the farmers through different educational and extension methods to reduce the extension gap for better pulse production in the district. The improved POP is more important with technological intervention for productivity and profitability of Chickpea. Detailed POP with technological intervention for DP. It was also observed that farmer's use in judicious and non-recommended insecticides and mostly did not use fungicides. Singh et al., (2011), Rachhoya et al., (2018), Biradar et al., (2020) and Singha et al., (2020) reported similar observations.

\section{Impact of CFLDs on varietal replacement and horizontal spread of different varieties of chickpea}

In the present investigation, efforts were made to study the evaluation of CFLDs on the horizontal spread of different varieties of Chickpea. It was marked from table 7 that CFLDs organized on Chickpea helped to increase the area under improved varieties in adopted villages. There was a significant increase in area from 125 to 550 ha under chickpea varieties viz., GNG 1581 and GNG 1958 (increased up to $29.41 \%$ ) in CFLDs programme. The reasons might be their agronomical attributes such as high yielding, wilt resistant varieties, less infestation of pest are recommended in Rajasthan state. The findings are in line with that reported by Patil, et al., (2018b).

CFLDs organized by the KVK had enhanced the yield of Chickpea vertically and ensured rapid horizontal expansion of recommended technologies of the crops. The CFLDs made a helpful and important increase in yield of Chickpea by 39.63 per cent. The CFLDs made a great impact on the use of improved varieties, weed management, fertilizer application, seed rate, seed treatment, plant protection measure and line sowing and adoption of other DP of Chickpea under investigation. Briefly, the overall trend in adoption of Chickpea crop production technologies by 29.45 per cent in adopted villages. The old mix varieties of pulse crops were replaced by improved cultivars on a large scale in selected villages. The area is under GNG varieties of Chickpea from 125.00 to 550.00 ha. This leads to conclude 
that CFLDs is proven extension intervention to demonstrate the production potential of Chickpea varieties on farmers' field.

Present investigation recommends that extension agencies engaged in transfer and application of agricultural technologies on farmers' field should give priority to organize CFLDs on large scale by adopting cluster approach for harness the productivity possible of Chickpea and to ensure rapid spread of flagship technologies developed by National Agricultural Research System (NARS). Furthermore, policy maker may provide adequate financial support to frontline extension system for organizing CFLDs under the close supervision of agricultural scientists and extension professionals. This varietal replacement strategy through CFLDs may help to increase the Chickpea productivity at micro, meso and macro level.

\section{Adoption of chickpea production technology}

The level of adoption of chickpea production technology by the partner farmers was measured for eleven important chickpea DP. The data have been presented in table 8 . As reflected in the table 8 , the partner farmers had fully adopted high yielding varieties on their fields. It can be also inferred that the mean percent score (MPS) pertaining to practices like, seed rate and spacing, time of sowing, irrigation management, seed treatment, fertilizer application and harvesting, threshing \& storage were 86.00, $74.62,71.25,68.50,65.70$ and 66.00, respectively. On the contrary, other practices such as weed management, physiological aspects, soil treatment and field preparation and plant protection measures were found to be least adopted with 39.65, 25.55, 22.30 and 18.75 MPS, respectively. This finding is in corroboration with the findings of Umrathiya et al., (2015).
In conclusion the findings above revealed that all the selected varieties of Chickpea namely; GNG 1581 and GNG 1958 gave higher yield in DP than FP in Dholpur district. There is a wide yield gap between research station technology and FP, which has resulted in lower yields in FP. The research station technology has the potential of doubling production at national level without increasing area under Chickpea, if farmers adopt the recommended POP.

The extension agencies should demonstrate effects of new technology in Chickpea production and inspire farmers for adoption of new technology to bridge this wide yield gap. Economic analysis on different parameters also revealed that net returns and additional gains were recorded higher in DP, which implies that the CFLDs programme is an effective tool for increasing the production, productivity and profitability of Chickpea and increasing knowledge, changing attitude and developing skill of farmers.

The present investigation calls for reducing the extension and technology gaps in these states through state specific research and extension programs. KVKs in Dholpur district have significant role to play towards effective transfer of improved Chickpea cultivation practices to farmers through their mandated activities including skill oriented training and other extension programmes with proper technical support. Farmers' awareness on DP through different innovative extension approaches including ICTs, FPOs, CIGs, FIGs, farmers' fairs/field days etc. as well as quality seed availability of improved varieties is the key factors in increasing productivity of Chickpea. The identified yield enhancing technology needs to be subsidized for wider adoption among the farmers in their local farming systems and enhancing production and productivity of Chickpea crops. 


\section{Acknowledgement}

Authors are highly thankful to the Director, ICAR-ATARI, Zone-II, Jodhpur, Rajasthan for providing funds for conducting the CFLDs and farmers who always show faith in the Krishi Vigyan Kendra, Dholpur. We are also thankful to the host organization Sri Karan Narendra Agriculture University, Jobner, Jaipur (Rajasthan).

\section{References}

Anonymous, (2020). Directorate of economics and statistics, Krishi Bhavan, New Delhi.

Biradar, S.A., Kolhar, B.C., Devarnavadagi, V.S., Rathod, S.C. and Hotkar, S. (2020). Effect of large-scale demonstration of Chickpea (Cicer arietinum L.) improved variety JG-11 under CFLD programme in Vijayapur district. International Journal of Chemical Studies. 8(4): 2279-2281.

Chand, H. and Khirbat, S.K. (2009). Chickpea wilt and its management - a review. Agricultural review. 30 (1):1-12.

Das, P. (2007). As quoted from: proceedings of the meeting of DDG (AE), ICAR, with officials of state departments, ICAR institutes and agricultural universities, NRC Mithun, Jharnapani on 5th October 2007, Zonal Coordinating Unit, Zone - III, Barapani, Meghalaya, India.

Das, S., Pagaria, P., Morwal, B.R. and Singh, M. (2018). Yield gap analysis for Chickpea (Cicer arietinum Linn) through cluster frontline demonstration under NFSM scheme in Barmer district of Rajasthan, India. International Journal of Current Microbiology and Applied Sciences. 7(09): 129-133.

Dayanand, V.R.K. and Mehta, S.M. (2012). Boosting mustard production through frontline demonstrations. Indian Research Journal of Extension Education. 12 (3): 121-123.

DES. (2018). Directorate of economics and statistics, department of agriculture cooperation and welfare, ministry of agriculture, government of India, New Delhi.

Gangwar, R.K., Shalini, Singh, T.P., Verma, L.N., Gupta, N.K. and Agarwal, N.K. (2013). Studies on the status of chickpea wilt in rajasthan. Agriways.1 (1): 38-41.

Hossain, A., Haque, A., Ahmad, M. and Prodhan, M.Z.H. (2010). Development of an integrated management approach for pod borer, Helicoverpa armigera (Hubner) on Chickpea. Bangladesh Journal of Agricultural Researchs. 35(2): 201-206.

IIPR Vision (2030). Printed \& Published by the Director. Indian Institute of Pulses Research (ICAR), Kanpur, Uttar Pradesh.

Krishna, K., Kanaujia, K.R. and Kanaujia, S. (2007). Role of plant density and abiotic factors on population dynamic of Helicoverpa armigera (Hubner) in Chickpea. Annals of Plant Protection Sciences. 15: 303-306.

Lathwal, O.P. (2010). Evaluation of crop demonstration on black gram in irrigated agro ecosystem. Annals of Agricultural Research, 31: 24-27.

Mitnala, J., Prasad B.G., Chowdary, K.R., Vijayabhinandana, B. and Rao, S.M. (2018). Impact of Cluster Frontline Demonstrations (CFLDs) on pulse production productivity, profitability and transfer of technologies in kurnool district of Andhra Pradesh, India. International Journal of Current Microbiology and Applied Sciences. 7(12): 937-947.

Nathawat, B.D.S., Sharma, O.P. and Yadav, A.L. (2020). Studies on the incidence of wilt disease in major Chickpea growing areas. International Journal of Chemical Studies. 8(3): 263-265.

Patil, A.A., Thakur, S., Naval, J.S., Narode, M.K., Kolhe, P.S. (2018a). Influence of intercropping on incidence of gram pod borer (Helicoverpa armigera) in Chickpea (Cicer arietinum L.). Journal of Entomology and Zoology Studies. 6(5): 12-15.

Patil, S.S., Mahale, M.M., Chavan, S.K.S. (2018b). Impact of Frontline Demonstrations (FLDs) on oilseeds crops 
in South Konkan coastal zone of Maharashtra. Current Agriculture Research Journal. 6(3): 355-364.

Pocket Book of Agricultural Statistics (2018). Government of India, Ministry of Agriculture and Farmers Welfare, Department of Agriculture, Cooperation and Farmers Welfare, Directorate of Economics and Statistics, New Delhi

Rachhoya, H.K., Sharma, M. and Saini, V.K. (2018). Evaluation of yield performance of Chickpea (Cicer arietinum) through cluster frontline demonstration. International Journal of Current Microbiology and Applied Sciences. 7 (05): 2465-2471.

Raj, A.D., Yadav, V. and Rathod, H.J. (2013). Impact of frontline demonstrations (FLD) on the yield of pulses. International Journal of Scientific and Research Publications. 3(9):1-4.

Raj Krishi (2018-19). Commissionerate of Agriculture, Rajasthan- Jaipur

Sagar, R.L, and Chandra, G. (2004). Frontline demonstration on sesame in West Begal. Agriculture. Extension Review.16: 7-10.

Samui, S.K, Maitra, S., Roy, D.K., Mandal, A.K. and Saha, D. (2003). Evaluation of front line demonstration on groundnut. Journal of the Indian Society Coastal Agricultural Research. 18 (2): 180-183.

Singh, G., Dhaliwal, N.S., Singh, J. and Sharma, K. (2011). Effect of frontline demonstrations on enhancing productivity of mustard. Asian Journal of Soil Science.
6: 230-33.

Singh, A.K., Singh, S.S., Prakash, V.E.D., Kumar, S. and Dwivedi, S.K. (2015). Pulses Production in India: Present Status, Bottleneck and Way Forward. Journal of Agri Search. 2 (2): 75-83.

Singha, A.K., Deka, B.C., Parisa, D., Nongrum, C. and Singha, A. (2020). Yield gap and economic analysis of cluster frontline demonstrations (CFLDs) on pulses in Eastern Himalayan Region of India. Journal of Pharmacognosy and Phytochemistry. 9(3): 606-610.

Umrathiya, K., Choudhary., S. and Swarnakar, V.K. (2015). Comparative study on adoption of improved Chickpea varieties in Indore district of M.P. IOSR Journal of Agriculture and Veterinary Science. 8 (10):01-08.

Venkattakumar, R., Ramanarao, S.V., Padmaiah, M. and Madhuri, P. (2010). Production constraints and information needs growers in Andhra Pradesh. Agricultural Extension Review. April- June, 21-24.

Verma, D.P. (2013). A study on impact of frontline demonstrations on pulses by Krishi Vigyan Kendra, Panna M.P. M.Sc. (Ag.) Thesis, Jawaharlal Nehru Krishi Vishwa Vidyalaya, Jabalpur MP.

Yadav, J.K., Singh, H.L. and Kumar, R. (2003). Determining selection components in Chickpea (Cicer arietinum L.). Plant Arch. 3 (1): $125-128$.

\section{How to cite this article:}

Laxman Prasad Balai, Navab Singh, D. R. Sharma, Madho Singh and Meena, S. M. 2020. Evaluation of Cluster Frontline Demonstrations on Production, Productivity, Profitability, Adoption and Horizontal Spread of Chickpea (Cicer arietinum Linn) in Dholpur District of Rajasthan, India. Int.J.Curr.Microbiol.App.Sci. 9(11): 3402-3413. doi: https://doi.org/10.20546/ijcmas.2020.911.406 